\title{
What do customers expect from social housing providers in the UK?
}

\author{
Amrit Sagoo \\ Department of Construction Management and Quantity Surveying, \\ Nottingham Trent University, \\ Shakespeare Street, Nottingham NG1 4FQ, UK \\ Email: Amrit.s.sagoo@ntu.ac.uk
}

\section{Malik M.A. Khalfan*}

School of Property, Construction and Project Management, RMIT University, Melbourne VIC 3001, Australia and

Department of Civil Infrastructure and Environmental Engineering, Khalifa University,

Abu Dhabi, UAE

Email: malik.khalfan@gmail.com

*Corresponding author

\begin{abstract}
This research presents a preliminary investigation to understand the customers' perception and expectations of service delivery in relation to social housing within the UK. The aim of this paper is firstly to present an overview of the customer and the main providers of social housing. Secondly, the paper explores the nature of service delivery in social housing and its importance in achieving customer satisfaction. Thirdly, this paper reports on the survey undertaken with 60 tenants (customers) residing with six registered social landlords (RSLs) during focus group workshops. The findings from the survey suggest that there are numerous factors that affect customer expectations including quality of accommodation, fair rent, value for money, services, and quality of repairs undertaken either as part of day to day repairs or in the form of planned maintenance.
\end{abstract}

Keywords: assets management in housing; social housing providers; registered social landlords; RSLs; social housing tenants; maintenance strategies; UK.

Reference to this paper should be made as follows: Sagoo, A. and Khalfan, M.M.A. (2017) 'What do customers expect from social housing providers in the UK?', Int. J. Sustainable Society, Vol. 9, No. 4, pp.294-310.

Biographical notes: Amrit Sagoo is serving as a Head of the Department of Construction Management and Quantity Surveying at the Nottingham Trent University. He has extensive teaching experience by working in the UK, Hong Kong, and Australia. 
Malik M.A. Khalfan has more than 19 years of research, teaching, consultancy and construction industry experience by working in the UK, Hong Kong, Pakistan, Australia, Singapore, Vietnam, Malaysia and the UAE. He has published more than 150 papers in refereed journals and conference proceedings.

\section{Introduction}

Over the past three decades, the social housing sector has undergone a huge transformation through changes in legislations, and regulations that resulted into increased effectiveness, and efficiency in managing the social housing provision (Jones and Sharp, 2012). The current changing paradigms, trends and economic conditions are forcing the social housing providers in the UK to adopt commercial social landlord approach; introduce tailor-made housing services to meet the varying requirements of the services users (customers); and adopt a holistic approach in managing the social housing. Customer satisfaction provides a measure as to whether the social housing providers are fully discharging obligations to their tenants. Hence, the strategic maintenance management of the social housing is important in order to achieve aim and objectives of the providers of the social housing and will create added value to customers' satisfaction. Current research in social housing have focussed on economics and modelling; health, ageing and disability, home ownership, homelessness and housing, housing affordability and rents, social wellbeing and housing policy (HMG, 2011; CIH, 2015) however, there is no research available that explores the nature of customer expectations of service delivery in UK social housing. This research is expected to lead to an understanding of the expectations and increased knowledge of the customer behaviour as an aid for the social housing providers to deliver a customer focused housing maintenance services. The objective of the research is to understand and examine the expectations of the social housing users resulting into development of customer focused housing maintenance strategies thereby leading to efficient and effective service delivery.

\section{The tenants/customers - who are they?}

The drive towards owner occupation has dramatically altered the nature of the social housing tenant. Figure 1 illustrates that there is a strong correlation between a person's economic status and household tenure, with the majority of today's social tenants belonging to the lowest income groups. The employment status of social tenants has changed over time, with a fall in the proportion of tenants being classified as 'unemployed', but with a significant increase in the number of tenants being classed as 'other inactive' or 'permanently sick' or 'disabled'. Social housing tenants are generally older, with $60 \%$ aged 45 or over and $30 \%$ aged 65 or over. 
This is a stark contrast with the private rented sector, where $70 \%$ of tenants are aged under 45, as shown in Figure 2.

There is a notable tenure difference between white and ethnic minority households. White households occupy $70 \%$ of properties, whereas their counterparts, ethnic minority occupy $45 \%$ of households. These figures suggest that ethnic minority families are less likely to own their own home than white occupants as illustrated in Figure 3.

Figure 1 Social employment status 1981 and 2006, (a) employment status by tenure (\%) (b) employment status of social renting householder of working age (\%) (c) household types in other inactive (\%) (see online version for colours)

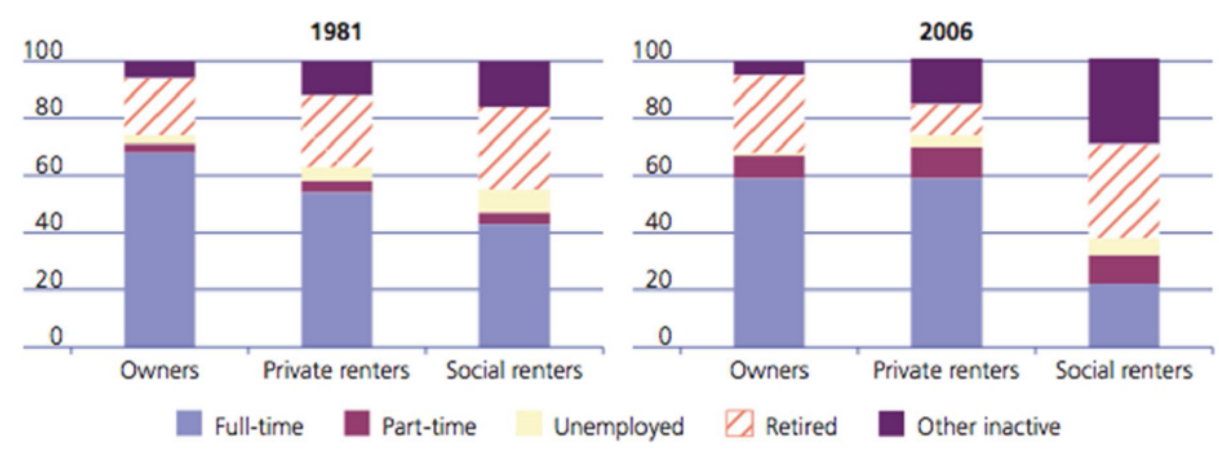

(a)

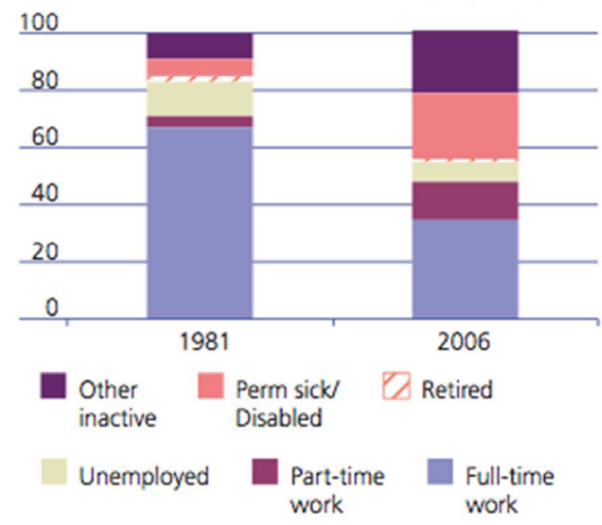

(a)

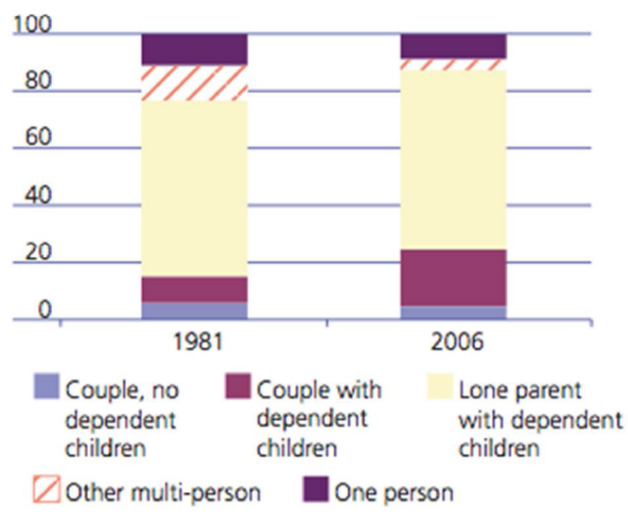

(b)

Source: Hills (2008) 
Figure 2 Distribution of age within tenure, 2008-2009 (see online version for colours)

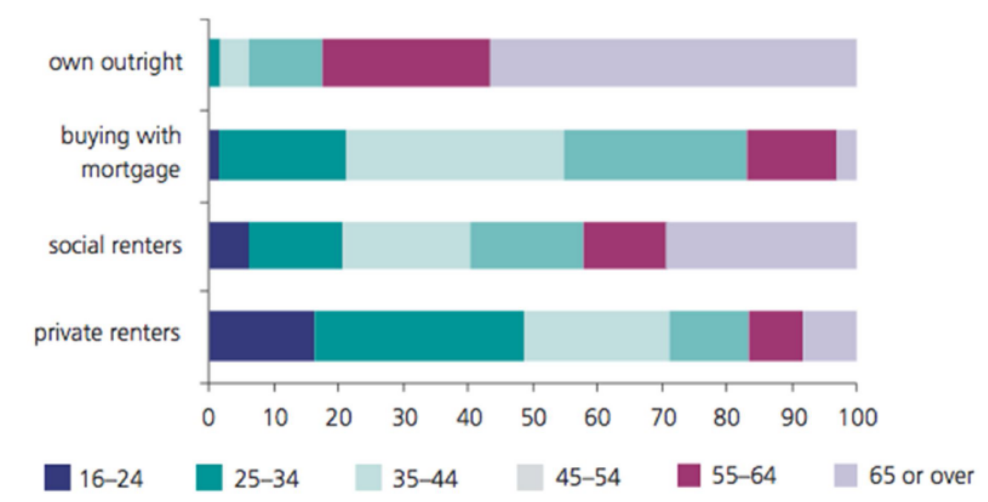

Source: DCLG (2009)

Figure 3 Tenure within ethnic group of occupants, 2008-2009 (see online version for colours)

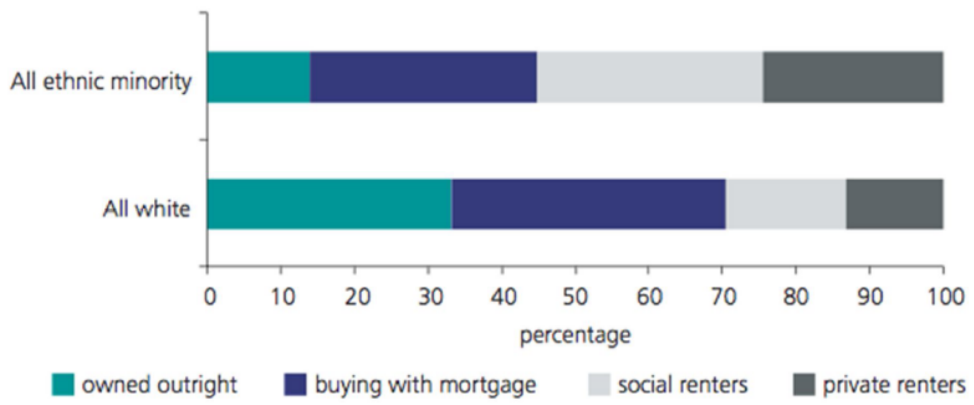

Source: DCLG (2009)

Hence, a variety of tenures is to be found in the public housing sector depending on an individual's situation but it is generally accepted by all registered social landlords (RSLs) that tenants can be classified based on their capacity to pay the rent, their personal circumstances, the physical and mental health condition. Sagoo (2014) grouped tenants broadly into the following categories; private tenants, affordable housing tenants, leaseholders, first time buyers, shared ownership, and sheltered. 


\section{The social housing providers}

According to Reader (2004), social housing can be sub-divided into two main categories: traditional social housing provided by the local authority and those provided by housing associations. The local authority housing departments were often linked with direct labour organisations (DLO) with the maintenance and repair being mainly carried out by the DLO. Under the Housing Act 1996, housing associations were classified as RSLs, rather than 'registered housing associations' as defined under the Housing Association Act 1985. RSLs have always outsourced their maintenance and repair services.

Table 1 Number of homes owned and/or managed by each organisation

\begin{tabular}{lc}
\hline Provider & Homes managed (approximate) \\
\hline Housing associations & $1,900,000$ \\
Local authorities & $1,300,000$ \\
ALMOs & 800,000 \\
Private 'for profit' sector & 0 (possible since 2004) \\
\hline
\end{tabular}

Source: Cave (2007)

However, due to the economic pressures during the late 1970s, the Thatcher administration radically transformed social housing and increased the accountability, improve efficiency and the effectiveness of social housing provision. This resulted in local authorities promoting voluntary stock transfers to housing associations and setting housing trusts (Malpass and Murie, 1999; Malpass, 2000; Stewart, 1996; DETR, 1997). These processes created a new context for the management and provision of social housing with local authorities ceasing to be the primary providers of social housing and were replaced in that role by arm's length management organisations (ALMOs) in the form of housing trusts and RSLs. Table 1 summarises the total number of homes being managed by social housing providers.

\section{Customer satisfaction and service delivery}

The concept of customer satisfaction varies from person to person and from one organisation to another. Numerous experts (Lester, 1936; Bearden and Teel, 1983; Hanan and Karp, 1989; Padilla, 1996; Gitomer, 1998; Wreden, 2004) have tended to focus varying attributes and differing levels of importance attached to 'customer satisfaction' and have been unable to reach an agreement on common definition of customer satisfaction. In its simplest form customer satisfaction varies from one person to another and satisfaction will often vary as a result of changes in circumstances. Customer satisfaction is defined as a business term which is used to capture the idea of measuring how satisfied customers are with the efforts of an organisation (Angelova and Zekiri, 2011), thus, positive customer satisfaction is crucial to any business to maximise its reputation and profit (Abd-El-Salamm, et al., 2013).

Within any service industry, achieving customer satisfaction and providing good quality service delivery to the customer is paramount for business survival (Lester, 1936); this is also true for property maintenance and the social housing sector (Chen et al., 2006). The concept of customer satisfaction in service delivery is not new and has formed 
the most basic marketing practices for many years involving several industries (Zemke and Schaaf, 1989; Luo and Hamburg, 2007). Therefore, within the modern competitive market, customer satisfaction is essential for providing distinction, increasing reputation and encouraging repeat customers (TICSI, 2014). To establish customer satisfaction, the approach of 'what the customer wants' will form a basis upon 'how to meet these expectations'. In recent years, customer satisfaction has been shown to form a key driver for continuous business improvement in social housing provision (Cave, 2007; Hills, 2008; DCLG, 2011). In order to provide a satisfactory service to its customers (tenants), RSLs need to consider many factors. They as providers of affordable social housing services must understand their customers: the needs, the expectation, and the ways of achieving their satisfaction. One of the most vital elements to achieve success is to ensure that the customer or client's needs are satisfied as much as possible (Shaw et al., 2010).

The social housing providers also need to consider the physical factors (building age, type of construction, its condition, inherent defects of the building, keeping the buildings functional and safe for the occupants with the minimum of disruption by carrying out maintenance repairs to the structure and fabric of the building) as well as the nonphysical factors associated with the service delivery which centres around the customer, the housing provider, policies and the standards. Service delivery should be customer focused and customer oriented activity (Eddie and Zheng, 2010). The way in which customers' needs are met and delivered should be addressed by supplying the services that are needed or in some cases demanded by the user (Eddie and Zheng, 2010). The customer, however, considers other softer issues, i.e., the 'people' skills of informing, listening, explaining, repairs reporting, customer liaison, cleanliness, quality control, appointments, and conduct of service personnel as an overall perception of service delivery. All of these need to be considered by maintenance managers if the customers were to have a favourable perception of good service delivery (Wordsworth, 2001; Eddie and Zheng, 2010). The expectations of the customer might sometimes be far greater than that supplied, it is therefore important that the customer is not given false hopes and promises. The service provider needs to be careful not to inflate the description of the service that can be provided to the customer (Olubodun, 2001; Audit Commission, 2002; Jones and Cooper 2007). The communication must therefore, be clear and transparent and the message being conveyed must explain the rationale of the 'why', the 'how' and the 'when' reasons and look for possible solutions.

The effective delivery of integrated services requires a robust model of practice which encompasses clear mechanisms for team working, integration and communication at all levels and not just about individual performances (Goodman, 2014). At the same time, each individual also needs to perform his or her duties correctly to enable the system to function satisfactorily. One of the ways to assist with this is to ensure that the RSL has an adequate personnel structure that provides support and provide consistent advice at all levels.

Eddie and Zheng (2010) focussed their research examining the relationship between direct and indirect associations of service quality (comprising staff-related attributes) and management quality (comprising facilities-related attributes) as a means of measuring customer satisfaction of facilities management (FM) in Hong Kong. Their findings indicate that both service and management quality have significant positive effect on customer satisfaction. Although the service quality has a stronger influence in attaining customer satisfaction than that of management quality but at the same time the service 
quality has a significant direct effect on management quality. While, Tucker and Pitt (2009a, 2009b, 2010) focussed more on establishing national customer satisfaction benchmarks in FM using benchmarking techniques and improving service provision in FM to enhance performance management strategies. However, purpose of this paper is to increase the awareness of what customers expect from their service providers. Service delivery on the other hand deals with the range of activities that are carried out by an individual or organisation in order to provide a service to a customer (Nash and Nash, 2002). In today's business climate, the emphasis is now firmly on providing a customer with the best service, with the aim to retain their custom (Brink, and Berndt, 2008; Gallagher, 2013). In this context of service delivery, ODPM (2003) states the principal objective of RSL is to keep the stock of publicly-owned social housing in good repair, ensuring lettable homes that satisfy tenant aspirations and preserve (though not enhance) their asset value. High quality maintenance is also crucial in ensuring the fulfilment of statutory repairing obligations and the protection of the health, safety and well-being of residents and also preventing the dwellings from falling into disrepair, through 'decent' standard (Sagoo et al., 2010). Often RSL's maintenance management department is seen by residents and tenants as a service provider of property and housing services, whose business it is to keep the property safe, at decent standard and functional with a minimum of disruption and disturbance (Mossel and Jansen, 2010). The maintenance department are involved in delivering satisfactory customer services to residents/tenants and organisations, and this will entail safe keeping the fabric of buildings and the services. Often, social residents will judge a maintenance service on how it has directly affected them rather than on the quality of the repair carried out (Wordsworth, 2001). Peters (2003) calls service delivery episodes as the 'moments of truth', and there are often times when residents will always remember or associate the service provider with bad experiences. Therefore, the degree of perceived client satisfaction with the overall service provided (rather than just the cost-efficiency of the repair and servicing work done) is a key indicator of service quality.

In achieving the overall goals, maintenance management departments invariably have to strike a balance between needs and available resources, which may or may not involve a divergence of goals between the owners and users of the building. Thus, it will rarely be the case that a maintenance management department has the resources to immediately fulfil every requirement and desire of the users (Mossel and Jansen, 2010).

Therefore, it is important to recognise customers' expectations with a focus on how social housing providers in the UK could enhance customer service delivery. Social housing providers (RSLs) are now competing with the private sector to become more economically viable. Therefore, there is a need to adopt a holistic approach in managing the social housing to meet the varying requirements of the users. This research would try to fill in the above gaps by analysing tenants perceptions related to quality of the housing, maintenance and affordability. And how all the above could be effectively and efficiently managed.

\section{Research methodology}

This research utilised the qualitative approach to collect data and used semi-structured interviews to collect data from the RSLs. The results from the interviews were disseminated and validated during number of focus group workshops attended by social 
housing tenants. The authors used these focus group workshops as opportunity to conduct the structured survey with the tenants as means to collect the data from the tenants. This paper focuses on the data collected during these focus group workshops from the social housing tenants.

Semi-structured interviews is one of the data collection tools as it provide a thorough, focused and trustworthy means of face to face information gathering with the interviewees (Lincoln and Guba, 1985; Blackstone, 2012; Bryman, 2012; Silverman, 2013). In this research, the semi-structured interview allowed customers to identify the key factors that affect customer expectations and satisfaction and helped develop an understanding of the underlying motivation and expectations of the customers.

The survey comprised of setting up six focus group workshops, each representing six housing organisations and RSLs. Twenty-five tenants were assigned to each focus group and were randomly selected by their housing organisation. Each of selected tenants was asked via invitation whether he/she would be interested in participating and approximately 15 tenants responded from each group indicating their willingness to participate in the workshop and the survey. During the workshop, a short presentation was also developed for the customers/tenants contextualising the basis of the survey. From the potential 15 customers, only ten tenants in each group attended the workshop and the survey sample represented 60 tenants. The workshop highlighted the following survey questions:

- Which do you feel are the most important services to you provided by your RSL?

- Which one is the most important service to you?

- How satisfied are you with the service providers' performance?

- Do you think the rent paid by tenants reflects value for money?

- Why do you rate your rent to represent good value for money?

- Why do you rate your rent to represent poor value for money?

- What changes are required for RSLs to provide a better value for money services?

\section{Results and discussions}

This section will discuss the results from the survey conducted during the focus group workshops.

\subsection{Which do you feel are the most important services to you provided by your RSL?}

The tenant's views on the importance attached to the services provided by the social landlord are tabulated in Table 2. Table 2 shows that $66 \%$ of the tenants (two thirds) reported that the repairs service is of the highest priority to them and inference of this data suggests that RSLs are falling short in their ability service the essential maintenance repairs. This may be due to the property age, condition, and perhaps the ability to produce an effective and an efficient maintenance strategy. The second highest important service was the quality of the accommodation and in joint third is dealing with nuisance from 
adjoining neighbours (anti-social-behaviour) and lower rents. This mirrors the concerns raised by Cave (2007) in that there is an unpleasant element in society and indeed the wider community that needs to handled very sensitively. Through the legislative framework RSL have to put in place policies, procedures and protocols linked with the enforcement authorities such as police and social services to adequately tackle the problems of anti-social-behaviour. The lower rents and affordability has mostly dominated the social housing sector when it was set and still plays a key issue. The fourth most important factor is customer services and least important is modernisation associated with wider estate management, the upkeep and maintenance of communal grounds. These findings are extremely useful as it reflects the views of tenants and that RSL's are failing to provide core services - response to maintenance repairs. This further reinforces the reasons as to why there is a need to examine and develop a robust decision support system for asset management.

Table 2 An evaluation of the importance of current services provided

\begin{tabular}{|c|c|c|c|c|c|c|}
\hline \multirow[b]{2}{*}{ Services } & \multicolumn{6}{|c|}{ Rating } \\
\hline & Very imp & $\operatorname{Imp}$ & Neith & $N I$ & $N A$ & Raking * score \\
\hline Efficient day to day repairs service & 16 & 50 & 10 & 14 & & 1 \\
\hline $\begin{array}{l}\text { Allocations, including managing waiting } \\
\text { lists for housing and requests for moves and } \\
\text { transfers }\end{array}$ & - & - & - & - & - & - \\
\hline Customer service & 10 & 30 & 10 & 10 & 40 & 4 \\
\hline Security/keeping the buildings & 6 & 30 & 6 & 58 & 8 & \\
\hline Involving tenants in decision making & - & - & - & - & - & - \\
\hline Dealing with anti-social behaviour & 6 & 10 & 20 & 30 & 34 & 6 \\
\hline Dealing with nuisance neighbours & 22 & 24 & 20 & 10 & 24 & 3 \\
\hline Complaints handling & - & - & - & - & - & - \\
\hline $\begin{array}{l}\text { Wider estate management/upkeep and } \\
\text { maintenance of communal grounds }\end{array}$ & 6 & 8 & 6 & 40 & 40 & 7 \\
\hline Taking tenants views into account/listening & - & - & - & - & - & - \\
\hline Good quality housing/accommodation & 30 & 30 & 20 & 10 & 10 & 2 \\
\hline $\begin{array}{l}\text { Major modernisation/upgrades/improvement } \\
\text { programmes (kitchens, bathrooms etc.) }\end{array}$ & 16 & 18 & 20 & 30 & 16 & \\
\hline Other please state Lower rents & 24 & 22 & 16 & - & 38 & 3 \\
\hline Nothing specific & - & - & - & - & - & \\
\hline Don't know & - & - & - & - & - & - \\
\hline
\end{tabular}

Notes: $*$ Ranking order $=$ very important + important $=$ score.

\subsection{Which one is the most important service to you?}

When the tenants were asked to select the most important service they perceived - see Table 3 for the results. The priorities of tenants were centred immediate on the core service provision of the RSL related to 'good quality accommodation' and 'everyday' services that directly affect the quality of tenants' lives on a daily basis as opposed to 
other services. The second most important service related to having a fair system for managing lists for housing, requests for moves and transfers which attracted an overall $14 \%$ response from the tenants, followed by dealing with anti-social behaviour $(10 \%)$ as being ranked the third important service; thus highlighting that some areas are deprived than others, affecting their daily wellbeing. Good customer services, major modernisation and improvement work both attracted a response of $8 \%$.

Table 3 An evaluation of the one most important service to you

\begin{tabular}{lcc}
\hline Service & Percentage response & Ranking \\
\hline A good day to day repairs service & 20 & 1 \\
Efficient maintenance of the estate and communal grounds & 8 & 4 \\
$\begin{array}{l}\text { Major modernisation and improvements work (e.g., kitchens } \\
\text { and bathroom upgrades) }\end{array}$ & 14 & 2 \\
A fair system, for managing waiting lists for housing and & 8 & 4 \\
requests for moves and transfers & 6 & 5 \\
Good customer service & - & \\
Effective complaints handling procedures & 10 & 5 \\
Keeping the buildings and entrances secure & 6 & 5 \\
Dealing with anti-social behaviour & 6 & 6 \\
Dealing with nuisance neighbours & 4 & 1 \\
Involving tenants in decision making & 20 & \\
Taking tenants views into account & & \\
The provision of good quality accommodation & & \\
\hline
\end{tabular}

The priorities of tenants were centred immediately on the core service provision of the RSL generally related to 'housekeeping' issues, i.e., the response to 'day to day' repairs is considered to be vital as customers may feel that this affects their lives and its importance is attached to the general quality and condition of the property. It was suggested that this may not be happening satisfactorily. The second most important service related to having a fair system for managing lists for housing, requests for moves and transfers which attracted an overall $14 \%$ response from the tenants. The inference of this factor may suggest that policies/procedures need to be made more transparent and clear for all tenants. Third and fourth ranking of most important core services are how well RSLs deal with anti-social-behaviour (ASB), 'good customer services' and 'dealing with nuisance', these factors highlight some areas are deprived and undesirable than compared to others and these issues affects their daily and their well-being.

Those services that are less likely to directly affect tenants are identified as 'effective complaints handling procedures', 'dealing with nuisance' and 'involving tenants in decision making' all three attracted an overall $6 \%$ response; taking tenants views into account (4\%). Clearly, these survey results for service priorities are based on the perceptions of tenants who primarily are service users and having first-hand experience of services received from the social landlord.

These core services are paramount to any organisation as well as social housing providers as an integral part of efficient and affective service delivery strategy. 


\subsection{How satisfied are you with the service providers' performance?}

To contextualise service priorities, the researcher also asked the tenants focus group as to how satisfied they were with their landlord's performance in providing services, the results are shown in Table 4. In analysing the results of this question, it is important to note that the results displayed previously in Table 3 shows the average percentages and there may be a huge variation in responses due to tenants background, age profile, location issues, type of accommodation (terrace, semidetached, maisonette, flat, etc.), quality of accommodation and their social housing provider (housing associations as opposed to the local authority/ALMO).

Table 4 An evaluation of how satisfied/dissatisfied are you with the performance of your housing provider

\begin{tabular}{|c|c|c|c|c|c|c|c|c|}
\hline \multirow{2}{*}{ Services } & \multicolumn{8}{|c|}{ Percentages overall } \\
\hline & $V S$ & $F S$ & $N$ & $F D$ & $V D$ & $N A$ & Satisfied* & Dissatisfied $^{* *}$ \\
\hline $\begin{array}{l}\text { Providing a good day to day repairs } \\
\text { service }\end{array}$ & 30 & 30 & 10 & 20 & 10 & - & 70 & 30 \\
\hline $\begin{array}{l}\text { Efficiently maintaining the estate } \\
\text { and grounds }\end{array}$ & 20 & 32 & 26 & - & 12 & 10 & 78 & 22 \\
\hline $\begin{array}{l}\text { Carrying out major modernisation }+ \\
\text { imp }\end{array}$ & 10 & 40 & 10 & 10 & 20 & 10 & 60 & 40 \\
\hline $\begin{array}{l}\text { Fair system for } \\
\text { waiting/moves/transfers }\end{array}$ & 12 & 28 & 20 & 8 & 22 & 10 & 60 & 40 \\
\hline Providing good customer service & 32 & 26 & 10 & 12 & 8 & 10 & 70 & 30 \\
\hline $\begin{array}{l}\text { Having effective complaints } \\
\text { handling }\end{array}$ & 18 & 30 & 12 & 18 & 16 & - & 66 & 34 \\
\hline $\begin{array}{l}\text { Keeping the buildings and entrances } \\
\text { secure }\end{array}$ & 30 & 46 & - & 12 & 12 & - & 76 & 24 \\
\hline Dealing with anti-social behaviour & 16 & 32 & 4 & 20 & 20 & 6 & 54 & 46 \\
\hline Dealing with nuisance neighbours & 12 & 38 & 8 & 6 & 38 & - & 56 & 44 \\
\hline $\begin{array}{l}\text { Involving tenants in decision } \\
\text { making }\end{array}$ & 22 & 28 & 10 & 14 & 18 & 8 & 60 & 40 \\
\hline Taking tenants views into account & 20 & 30 & 12 & 16 & 26 & - & 62 & 42 \\
\hline $\begin{array}{l}\text { Providing good quality } \\
\text { accommodation }\end{array}$ & 28 & 38 & 10 & 24 & - & - & 76 & 24 \\
\hline
\end{tabular}

Notes: VS $=$ Very Satisfied

$\mathrm{FS}=$ Fairly Satisfied

$\mathrm{N}=$ Neither

$\mathrm{FD}=$ Fairly Dissatisfied

$\mathrm{VD}=$ Very Dissatisfied

$\mathrm{NA}=$ not applicable

*Satisfied $=$ very satisfied + fairly satisfied + neither

$* *$ Dissatisfied $=$ fairly dissatified + very dissatisfied + do not know

According to the Table 4, the tenants identified that they were satisfied with their landlord's performance for efficiently maintaining the estate and communal grounds (78\%), good quality accommodation and keeping building entrance and security both having equal preferences $(76 \%)$ followed by day to day repair services $(70 \%)$. Having 
effective complaints handling procedures $(66 \%)$, taking tenants' views into account $(62 \%)$, carrying out major modernisation and improvement work, involving tenants in decision making and fair system associated with waiting / transfer all attaining 60\% response. The worst dissatisfaction responses were associated with dealing with anti-social behaviour and nuisance neighbours.

\subsection{Do you think the rent paid by tenants reflects value for money?}

As well as establishing the tenants perception on the level of service (satisfaction, and priorities) the survey also probed into the tenants' perception of value for the services delivered by social housing providers in relation to the amount of money paid in rent. The results are shown in Table 5, which indicate the majority of tenants $(66 \%)$ rated the accommodation and services provided by their landlord as representing good value for money.

Table 5 An evaluation of resident's response to 'value for money' services provided by the social housing provider

\begin{tabular}{lc}
\hline Very good value & $32 \%$ \\
Fairly good value & $34 \%$ \\
Neither good nor poor value & $8 \%$ \\
Fairly poor value & $8 \%$ \\
Very poor value & $6 \%$ \\
Do not know & $4 \%$ \\
\hline
\end{tabular}

\subsection{Why do you rate your rent to represent good value for money?}

Table 6 displays the results of the tenants' perception as to the reasons why they feel they are getting value for money. $36 \%$ of the tenants felt good value money was being associated with the provision of good standard of accommodation whilst $30 \%$ of the tenants viewed that rents were reasonable.

Table 6 An evaluation of the reasons why it's good value for money

\begin{tabular}{lcc}
\hline Services & $\begin{array}{c}\text { Percentage } \\
\text { response }\end{array}$ & $\begin{array}{c}\text { Ranking } \\
\text { order }\end{array}$ \\
\hline They make sure important services are looked after & 8 & 3 \\
Work is carried out promptly & 8 & 3 \\
Services are performed to a high standard & 6 & 4 \\
Rent is reasonable & 30 & 2 \\
Landlord keeps residents informed of what is going on & 36 & - \\
Good standard of accommodation/living conditions & 4 & 5 \\
Good standard of facilities and amenities & - & - \\
Landlord listens to tenants/Involve tenants in decision making & 8 & 3 \\
Landlord makes improvements/modernisations to my home & - & - \\
Other please state.............. & - & - \\
Do not know & & 5
\end{tabular}


The other explanations received a low response from the tenants, these were 'work carried out promptly', 'important services by the landlord' and landlords improvements/modernisation each receiving an $8 \%$ response, whilst, 'services are performed to a high standard' and 'good standard of facilities and amenities only received $6 \%$ and $4 \%$ response.

\subsection{Why do you rate your rent to represent poor value for money?}

The explanation given by the tenants who rated the service provided by their landlord represent poor value for money were also strongly related to the quality of accommodation (28\%) and cost of rent (20\%) see Table 7.

Table 7 An Evaluation of the reasons why its poor value for money

\begin{tabular}{lcc}
\hline Services & Percentage response & Ranking order \\
\hline Important services are not provided & 8 & 4 \\
Take too long to carry out work & 8 & 4 \\
Services are performed to a low standard & 8 & 4 \\
Rent is too high & 20 & 2 \\
Residents are not kept informed about what is going on & - & 1 \\
Poor standard of accommodation/living conditions & 28 & 3 \\
Poor standard of facilities and amenities & 12 & 5 \\
Landlord does not listen to tenants/Involve tenants & 4 & 3 \\
Landlord does not make improvements/modernisations & 12 & \\
to my home & & \\
\hline
\end{tabular}

The focus on the quality of accommodation as the core reason for landlords providing good or poor value for money was also reflected in the discussion during focus group workshops. It was apparent in discussions with tenants that receiving good services was the central consideration and more important than the cost of rent. More specifically, the tenants believed that the value for money is linked to key services being delivered effectively and furthermore, the difference between receiving good/poor value for money hinged on having suitable accommodation that catered for their needs and circumstances.

\subsection{What changes are required for RSLs to provide a better value for money services?}

Furthermore, the tenants were asked what changes/improvements would they like their landlords to make to enable significant improvements to increase the value for money tenants receive; Table 8 highlights the feedback provided by the tenants. Interestingly the tenants raised issues on the core provision of the social landlords and would like to see a significant improvement in the services delivery related to 'improved quality of facilities' and 'efficient repairs' both received a $20 \%$ response while 'keeping property in good condition' and 'modernising properties' received a $14 \%$ vote; better control of cost and fiscal management had $12 \%$ agreement; 'listening to tenants' received $10 \%$ response; and afford rent had a least amount of response and $2 \%$ of the respondents to the survey proposed no changes. 
The response to the question demonstrates the tenant's desire and the expectation that the service provider should pay more attention to maintain quality of housing and provide quality of the repairs. This presents huge challenges for social housing providers, where the housing stock is ageing (or aged) and external envelope (roof, chimney stacks, lead flashing, rainwater gutters and down pipes, windows, doors, external walls, boundary walls/fences) is rapidly deteriorating which means that RSLs, who often play a 'catch up' repairing properties on ad-hoc basis, need to constantly upgrade these building to meet the current decent homes standard.

Table 8 An evaluation of what changed needs to be made to allow better value for money

\begin{tabular}{lc}
\hline Improvements & Percentage response \\
\hline Better cost control/fiscal management & 12 \\
Modernising/upgrading properties & 14 \\
Listening to tenants & 10 \\
Keeping property in good condition & 14 \\
Ensure rents are affordable & 8 \\
More efficient/quality repairs & 20 \\
Improved quality of service facilities & 20 \\
No change - we get better value for money & 2 \\
Do not know & - \\
Others & - \\
\hline
\end{tabular}

\section{Conclusions}

The importance of customer service delivery and customer expectation has been recognised by many researchers and business organisations in the past decades. With a focus on customer expectations, this paper provided an overview of the primary research undertaken within a wider study focusing on how social housing providers could enhance customer service delivery through formulating housing maintenance management strategies and embedding it within organisations business culture.

Given the current economic climate, the government in UK is placing more emphasis on social housing providers to compete with the private sector and adopt corporate social landlord strategies to become more economically viable. Social Housing providers therefore, must adopt a holistic approach in managing the social housing and a commercial approach must be adopted to tailor make housing services to meet the varying requirements of the users.

The analysis presented in this paper concludes that as far as the tenants are concerned, they fully understand the core services provided by the service provider and their expectations of the services. These relate to housing quality (accommodation and day to day repairs), upgrading existing housing stock, value for money of the rent payment, listening to the tenants' voice, and affordable rents. In order for social housing providers to deliver customer orientated housing maintenance services, they must fully understand their service users and their expectations. 
The findings of this study could play an important role in developing customer expectations strategies by RSLs to maintain and manage both the housing stock and the tenants.

\section{References}

Abd-El-Salamm, E.M., Shawky, A.Y., and El-Nahas, T. (2013) 'The impact of corporate image and reputation on service quality, customer satisfaction and customer loyalty: testing the mediating role. Case analysis in an international service company', The Business and Management Review, Vol. 3, No. 2, pp.177-196.

Angelova, B. and Zekiri, J. (2011) 'Measuring customer satisfaction with service quality using american customer satisfaction model (ACSI Model)', International Journal of Academic Research in Business and Social Sciences, Vol. 1, No. 3, pp.232-258.

Audit Commission (2002): Housing Repair and Maintenance Handbook, Audit Commission Publications.

Bearden, W.O. and Teel J.E. (1983) 'Selected determinants of consumer satisfaction and complaint reports', Journal of Marketing Research, Vol. 20, No. 1, pp.21-28.

Blackstone, A. (2012) Principles of Sociological Inquiry: Qualitative and Quantitative Methods, Flat World Knowledge, Nyack, New York.

Brink, A. and Berndt, A. (2008) Relationship Marketing and Customer Relationship Management, Juta and Co Ltd., Lansdowne, South Africa.

Bryman, A. (2012) Social Research Methods, 4th ed., Oxford University Press.

Cave, M. (2007) Every Tenant Matters: A Review of Social Housing Regulation, DCLG publications, London.

Chen, H.S., Yang. C.C., Shiau, Y.H., and Wang, H.H. (2006) 'The development of an employee satisfaction model for higher education', The TQM Magazine, Vol. 18, No. 5, pp.484-500.

CIH (2015) UK Housing Review [online] http://www.cih.org/publication/display/vpathDCR/ templatedata/cih/publication/data/UK Hou sing Review 2015 (accessed 16 April 2015).

DCLG (2011) Laying the Foundations: A Housing Strategy for England, DCLG Publications, London.

Department for Communities and Local Government (DCLG) (2009) English Housing Survey 2008-2009, DCLG Publications, London.

Department of the Environment Transport and the Regions (DETR) (1997) Guidance on the Conduct of Compulsory Competitive Tendering, DETR, London.

Eddie, C.M. and Zheng, H.X. (2010) 'Measuring customer satisfaction of FM service in housing sector', Facilities, Vol. 28, Nos. 5/6, pp.306-320.

Gallagher, R. (2013) The Customer Service Survival Kit, AMACON Publishers, New York.

Gitomer, J. (1998) Customer Satisfaction is Worthless: Customer Loyalty is Priceless, Bard Press, Austin.

Goodman, J.A. (2014) Customer Experience 3.0: High-Profit Strategies in the Age of Techno Service, Amercian Management Association.

Hanan, M. and Karp, P. (1989) Customer Satisfaction: How to Maximize, Measure, and Market Your Company's 'Ultimate Product', American Management Association, New York.

Hills, J. (2007) Ends and Means: The Future Roles of Social Housing in England, CASE report 34, London School of Economics, ESRC Centre for Analysis of Social Exclusion, London.

Hills, J. (2008) 'Social housing in the 21st century: four key issues that need urgent attention', Britain in 2008, pp.95-95, Economic and Social Research Council, Swindon. 
HMG (2011) Laying the Foundations - A housing Strategy for England, HM Government, London.

Jones, K. and Cooper, J. (2007) 'The role of routine maintenance in improving the sustainability of existing social housing' in the Proceedings of the International Conference on Sustainable Urban Areas, 25-28 June, Rotterdam.

Jones, K.G. and Sharp, M. (2012) 'Perceived inefficiency and waste in the social housing maintenance process', International Journal of Construction Innovation, Vol. 12, No. 4, pp.414-428.

Lester, B. (1936) ;Changing methods in the marketing of industrial equipment', Journal of Marketing, Vol. 1, No. 1, pp.46-52.

Lincoln, Y.S. and Guba, E.G. (1985) Naturalistic Inquiry, Newbury Park, Sage, CA.

Luo, X. and Hamburg, C. (2007) 'Neglected outcomes of customer satisfaction', Journal of Marketing, Vol. 71, No. 2, pp.133-149.

Malpass, P. (2000) Housing Associations and Housing Policy, A Historical Perspective, MacMillan Press Ltd., Hampshire.

Malpass, P. and Murie, A. (1999) Housing Policy and Practice, 5th ed., Macmillan, London.

Mossel, H.V. and Jansen, S.J.T. (2010) 'Maintenance services in social housing: what do residents find important?', Structural Survey, Vol. 28, No. 3, pp.215-229.

Nash, S. and Nash, D. (2002) Deliver Outstanding Customer Service, 2nd ed., How to Books Ltd Publishers, Oxford.

ODPM (2003) Best Value and Performance Improvement, Circular 3/2003, ODPM London.

Olubodun, F. (2001) 'A multivariate approach to the prediction of maintenance needs in public housing: the tenant dimension', Structural Survey, Vol. 19, No. 2, pp.133-142.

Padilla, R.A. (1996) Literature Review on Consumer Satisfaction in Modern Marketing, Seminar in Consumer Research, Faculty of Commerce and Administration, Concordia University [online] http://pages.infinit.net/rodrigo/satisfaction.html (accessed 16 April 2015).

Peters, T. (2003) Re-Imagine!: Business Excellence in a Disruptive Age, Dorling Kindersley Publishers Ltd, London.

Reader, P. (2004) Efficient and Cost Effective Procurement of Housing Maintenance Services, Housing Quality Network.

Sagoo, A. (2014) A Decision Support System for Evaluating Local Authority Housing Maintenance Strategies in the United Kingdom, Unpublished $\mathrm{PhD}$, University of Derby.

Sagoo, A., Okoroh, M., Jones, C., and Shira, T. (2010) 'A critical evaluation of asset management factors used in delivering seamless property services in West Midlands - a decent homes approach', in the Proceedings of Third World of Construction Project Management Conference (WCPM 2010), 20-22 October 2010, Coventry University.

Shaw, C., Dibeehi, Q., and Walden, S. (2010) Customer Experience: Future Trends and Insights, Palgrave MacMillan, New York.

Silverman, D. (2013) Doing Qualitative Research, 4th ed., Sage, London.

Stewart, A. (1996) Rethinking Housing Law, Sweet and Maxwell, London.

TICSI (2014) The International Customer Service Standard [online] http://www.ticsi.org (accessed 22 March 2015).

Tucker, M. and Pitt, M. (2009a) 'Customer performance measurement in facilities management: a strategic approach', International Journal of Productivity and Performance Management, Vol. 58, No. 5, pp.407-422.

Tucker, M. and Pitt, M. (2009b) 'National standards of customer satisfaction in facilities management', Facilities, Vol. 27, Nos. 13/14, pp.497-514.

Tucker, M. and Pitt, M. (2010) 'Improving service provision through better management and measurement of customer satisfaction in facilities management', Journal of Corporate Real Estate, Vol. 12, No. 4, pp.220-233. 
Wordsworth, P. (2001) Lee's Building Maintenance Management, 4th ed., Wiley-Blackwell.

Wreden, N. (2004) Whats Better Than Customer Satisfaction? [online] http://www. destinationCRM.com (accessed 6 May 2015).

Zemke, R. and Schaaf, D. (1989) The Service Edge: 101 Companies that Profit from Customer Care, New American Library, New York. 